\title{
MODEL PEMBELAJARAN TARI KREATIF \\ MELALUI PENGEMBANGAN BISINDO PADA SISWA TUNA RUNGU DI SMPLB-B BUDI NURANI KOTA SUKABUMI
}

\author{
Yulia Hendrilianti \\ SMPN 5 Sukabumi \\ yhendrilianti@gmail.com
}

\begin{abstract}
ABSTRAK
Penelitian ini membahas tentang bagaimana mengajarkan tari kreatif pada siswa tunarungu kelas 8 SMPLB-B Budi Nurani Kota Sukabumi dengan mengembangkan kode-kode yang ada dalam Bisindo yang mirip dengan gerakangerakan tari sesuai dengan ritmik tari. Bagi siswa tunarungu, menari sesuai dengan ritmik adalah sesuatu yang relatif sulit karena membutuhkan beberapa kode visual yang merepresentasikan gerakan-gerakan tertentu dalam menari. Melalui model pembelajaran ini, peneliti berupaya untuk mengadaptasi kode-kode Bisindo yang familiar bagi siswa tunarungu untuk digunakan dalam menari. Dengan menggunakan kode-kode ini, para siswa terampil dan mampu berpikir kritis serta menciptakan gerakan-gerakan tari yang diadaptasi dari kode-kode Bisindo.
\end{abstract}

Kata kunci: model pembelajaran, tari kreatif, isyarat jari bisindo, siswa tuna rungu

\section{ABSTRACT}

The research focused on teaching deaf students of Grade 8 SMPLB-B Budi Nurani in Sukabumi city creative dance based on particular codes of Bisindo that resemble dancing moves and rythms. For deaf students, dancing in harmony to the rythm is relatively difficult as it requires particular visual codes that represent the rythm or movement of a dance. In this learning model, the researcher attempted to adapt Bisindo codes, which are familiar to deaf students, for instructing deaf students in a dance performance. Through the use of this codes in giving instruction in a dance, the deaf students are capable of doing critical thinking, innovating, and creating new dance movements, which are adapted from Bisindo codes.

Keywords: learning model, creative dance, bisindo codes, deaf students

\section{PENDAHULUAN}

Undang-Undang Nomor 20 Tahun 2003 tentang Sistem Pendidikan Nasional Pasal 3, menyatakan bahwa tujuan pendidikan nasional adalah berkembangnya potensi peserta didik agar menjadi manusia yang beriman, dan bertakwa kepada Tuhan Yang Maha Esa, berahlak mulia, sehat, berilmu, cakap, kreatif, mandiri, dan menjadi warganegara yang demokratis dan bertanggung jawab. Melalui pendidikan, peserta didik dibentuk menjadi warga negara yang demokratis, dan bertanggung jawab, yaitu mampu menghargai perbedaan dan partisipasi dalam masyarakat.

Sistem pendidikan Nasional harus mampu menjamin pemerataan kesempatan pendidikan, peningkatan mutu serta relevansi dan efisiensi manajemen pendidikan untuk menghadapi tantangan sesuai dengan tuntutan perubahan kehidupan lokal, nasional, dan global sehingga perlu dilakukan pembaharuan pendidikan secara terencana, terarah, dan berkesinambungan.

Pendidikan nasional bertujuan mencerdaskan kehidupan bangsa dan mengembangkan manusia Indonesia seutuhnya, yaitu manusia yang beriman dan bertakwa terhadap Tuhan Yang Maha Esa dan berbudi pekerti luhur, memiliki pengetahuan dan keterampilan kesehatan jasmani dan rohani, kepribadian yang mantap dan mandiri, serta rasa tanggung jawab kemasyarakatan dan kebangsaan.

Untuk mencapai tujuan pendidikan nasional tersebut, maka pencapaiannya dibebankan kepada masing-masing institusi/lembaga pendidikan sesuai dengan jenis pendidikan dan tujuan kelembagaan pendidikan. 
Selanjutnya, dikembangkan masing-masing, pencapaiannya tentu dibebankan pada penyelenggaraan setiap bidang studi/mata pelajaran.

Sekolah adalah sebuah organisasi yang mewadahi proses kegiatan administrasi, dimana ada sejumlah orang yang terlibat aktif melakukan kegiatan kerja sama atas dasar rasionalitas dan formalitas tertentu dalam rangka pencapaian tujuan pendidikan. Sekolah sebagai organisasi mengandung unsur-unsur: manusia, tujuan yang ingin dicapai, tugas-tugas, wewenang, struktur, hubungan formalitas serta sarana prasarana.

Tenaga kependidikan adalah anggota masyarakat yang mengabdikan diri dan diangkat untuk menunjang penyelenggaraan pendidikan. Pendidik adalah tenaga kependidikan yang berkualifikasi sebagai guru, dosen, konselor, pamong belajar, widya iswara, tutor, instruktur, fasilitator, dan sebutan lain yang sesuai dengan kekhususannya, serta berfartisipasi dalam menyelenggarakan pendidikan.

Proses belajar mengajar merupakan interaksi atau hubungan timbal balik antara siswa dengan guru dan antara sesama siswa dalam proses pembelajaran. Pembelajaran dijelaskan pula dalam undang - undang RI tentang sistem pendidikan nasional tahun 2003 adalah proses interaksi peserta didik dengan pendidik dan sumber belajar pada suatu lingkungan belajar. Peserta didik adalah anggota masyarakat yang berusaha mengembangkan potensi diri melalui proses pembelajaran yang tersedia pada jalur, jenjang, dan jenis pendidikan tertentu.

Guru mempunyai kedudukan atau posisi yang sangat penting dan menentukan. Guru merupakan ujung tombak yang strategis, karena berhadapan langsung dengan sasaran tugasnya,yaitu peserta didik. Tugas guru harus mampu membina siswa mentransformasikan dirinya, mengembangkan sikap dan kepribadiannya (attitude dan personality), mengembangkan kemampuan berpikir atau kecerdasan (knowledge) serta melatih keterampilan baik intelektual atau psikomotor (skill).

Metode pengajaran harus mempertimbangkan keadaan/kesediaan peserta didik. Kemampuan dan karakteristik peserta didik itu unique. Kecocokan suatu metode itu juga sebetulnya relatif. banyak ragam metode pengajaran. Masing-masing metode memiliki kelebihan/kebaikan dan kekurangan/ kelemahan. Ketepatan dan kebaikan metode pengajaran adalah jika ia dapat mendukung dan didukung oleh faktor-faktor pengajaran.

Siswa tunarungu adalah siswa yang mengalami kekurangan atau kehilangan kemampuan mendengar. Sutjihati, (2007:93) yang menyebutkan bahwa "tuna rungu adalah suatu keadaan kehilangan pendengaran yang mengakibatkan seseorang tidak dapat menangkap berbagai rangsangan, terutama melalui indera pendengarannya. Anak tuna rungu adalah anak yang kehilangan pendengarannya baik sebagian atau seluruhnya yang menyebabkan pendengarannya tidak nilai fungsional didalam kehidupan sehari-harinya, meskipun pada hakekatnya anak tuna rungu memiliki potensi yang tidak jauh berbeda dengan anak yang normal pendengarannya. Ketunarunguannya berdampak menjadi gangguan pada kehidupannya, cara belajarnya memerlukan upaya yang sungguh-sungguh harus menggunakan teknik dan metode serta strategi pembelajaran yang tepat, sehingga memudahkan pemahaman oleh anak. Selain itu pendapat Mufti Salim (Somantri, 2006:93) memberi batasan bahwa:"Anak tunarungu adalah anak yang mengalami kekurangan atau kehilangan kemampuan mendengar yang disebabkan oleh kerusakan atau tidak berfungsinya sebagian atau seluruh alat pendengaran, sehingga mengalami hambatan dalam perkembangan bahasanya. Ia memerlukan bimbingan pendidikan khusus untuk mencapai kehidupan lahir batin yang 
layak".

Siswa tunarungu memiliki hak yang sama seperti anak yang tidak berkebutuhan khusus dalam hal pendidikan, hal ini tercantum pula dalam Undang-Undang Nomor 20 tahun 2003 pasal 5, yang menyatakan bahwa "setiap warga negara mempunyai hak yang sama untuk memperoleh pendidikan yang bermutu, dan warga negara yang memiliki kelainan fisik, emosional, mental, intelektual, dan/atau sosial berhak memperoleh pendidikan khusus". Penggunaan strategi pembelajaran pada siswa tunarungu harus bersifat visual, lebih memanfaatkan indera penglihatan, proses pembelajaran siswa tuna rungu hendaknya diilustrasikan dalam bentuk visual, disebabkan tidak berfungsinya pendengaran.

Seni Budaya adalah bidang seni yang memiliki cakupan yang sangat luas, ada seni rupa, musik, tari dan teater. Seni yang terintegrasi dengan budaya menghasilkan keragaman seni dengan berbagai ciri khas yang dimilikinya. Dalam mata pelajaran seni budaya, aspek budaya tidak dibahas secara tersendiri, tetapi terintegrasi dengan seni, oleh karena itu, mata pelajaran Seni Budaya pada dasarnya merupakan pendidikan seni yang berbasis budaya.

Pelajaran Seni Budaya diberikan dengan tujuan untuk memberikan pengalaman estetik pada siswa dalam bentuk kegiatan berekpresi/berkreasi dan berprestasi. Peran ini tidak dapat diberikan oleh mata pelajaran lain, hasil dari pembelajaran Seni budaya ini diharapkan dapat membentuk pribadi siswa yang harmonis dan memiliki multi kecerdasan. Siswa dibentuk agar mampu mengembangkan bakat dan kreativitasnya sesuai dengan pilihan dengan potensi diri yang dimiliki para siswa.

Tujuan akhir pendidikan seni budaya tidak hanya menciptakan siswa yang cerdas tetapi juga siswa yang jujur, bertanggung jawab, dan peduli terhadap sesama. Materi seni budaya tidak sekedar mengajarkan mereka ahli dibidang seni, namun harus memasukan nilai-nilai luhur yang akan membentuk siswa berperilaku berkarakter, sehingga karakter nilai-nilai bangsa dapat diaplikasikan dalam kehidupan siswa sehari-hari.

Seni tari yang diajarkan di sekolah merupakan suatu media ekspresi bagi siswa, demikian juga dengan siswa yang memiliki keterbatasan pendengaran (tuna rungu), tentu keterbatasan itu bukan suatu penghalang bagi siswa tunarungu untuk berekpresi, karena mereka juga mampu mengungkapkan ekspresinya dengan baik meski sekalipun keterbatasan fisik akan sedikit memberi hambatan dalam belajar, terutama ketika berkomunikasi pada saat belajar menari.

Tujuan pembelajaran seni tari bagi pelajar adalah untuk mengekpresikan kembali pengalaman mereka yang lalu secara kreatif, memupuk dan mengembangkan daya ciptanya dan diekpresikan dalam bentuk seni karya tarian kreatif. Dalam penelitian ini penulis merancang tari kreatif yang mengembangkan bahasa komunikasi tunarungu (Bisindo) dalam media pembelajaran yang dapat meningkatkan kreativitas siswa, aspek apektif, kognitif dan psikomotor yang merupakan bagian penting dalam pengembangan pembelajarannya.

Tari kreatif menurut Gilbert yang dikutip oleh Desfina (2002:3-7) mengatakan menggabungkan penguasaan pergerakan melalui seni ekpresi. Ia adalah gabungan kedua-duanya menumbuhkan sesuatu yang menjadikan tarian kreatif sangat kuat. Ia juga mengatakan pembelajaran seni tarian sekolah dapat mengembangkan cognitive autcomes, afective autcome, physical autcomes, social autcome.

Bagi siswa normal, mungkin tidak akan memiliki kendala dalam pendengaran, sehingga tidak akan menemukan hambatan dalam memperagakan gerakan sesuai irama. Namun bagi siswa tuna rungu, ini merupakan 
suatu kesulitan yang membutuhkan strategi khusus dalam pembelajaranya, dengan demikian penggunaan bahasa isyarat, akan mempermudah pemahaman dalam pembelajaran seni tari. Cara berkomunikasi dengan melibatkan bahasa verbal, bahasa isyarat dan bahasa tubuh bagi tunarungu akan mempermudah siswa dalam memahami pembelajaran seni tari.

Dinegara Indonesia ada simbol bahasa isyarat yang disebut Bisindo (Bahasa Isyarat Indonesia). Bisindo adalah bahasa isyarat Indonesia. Bahasa isyarat adalah bahasa yang mengutamakan komunikasi manual, bahasa tubuh, dan gerak bibir, bukannya suara, untuk berkomunikasi. Bahasa isyarat tidak menggunakan kata-kata ataupun tanda baca tetapi menggunakan gerak yang berupa isyarat yang lazimnya sudah dimengerti oleh pelaku dan penerima. Itulah sebabnya bahasa isyarat disebut juga komunikasi non verbal yaitu bahasa yang tidak memakai katakata sama sekali dan merupakan bagian dari komunikasi.

Bahasa isyarat pada siswa tunarungu sangat berperan penting, sebab bahasa isyarat jauh lebih baik daripada ucapan-ucapan sehingga mudah dimengerti oleh siswa tunarungu. Salah satu contoh isyarat yang masih lazim digunakan seperti bahasa isyarat dengan mengangkat kedua bahu berarti mengekspresikan ketidaktahuan atau tidak mengerti apa yang sedang dibicarakan kemudian dengan mengacungkan jari jempol merupakan isyarat tanda persetujuan dan tanda kebenaran.

Pengajaran seni tari dengan menggunakan isyarat, tentu akan mempermudah proses belajar menari bagi siswa tunarungu, dengan melihat isyarat jari atau tangan yang dilakukan guru, maka anak tunarungu mudah memahami kode-kode tari yang disampaikan guru serta mudah dalam penyampaian materi tari yang disesuaikan dengan ritmiknya selama pembelajaran berlangsung.
Pengembangan Bisindo dalam pembelajaran seni tari khususnya, sebagai pengantar materi dan instruksi guru pengajar dalam praktek menari. Dalam seni tari terdapat beberapa simbol kosakata yang melambangkan gerak tertentu yang penggunaan istilah tersebut hanya digunakan dalam bahasa tari. Contoh dari simbol kosakata tersebut adalah gedig, trisi, capang, sembah dan beberapa istilah lainnya. Untuk memudahkan penyampaian materi maka dibuat beberapa istilah agar mempermudah penyampaian materi dengan simbol yang dipergunakan mirip dengan Bisindo, yang intinya mempergunakan jari dan tangan untuk mengganti bahasa verbal atau menyimbolkan pernyataan tertentu.

\section{METODE PENELITIAN}

Penelitian ini dilaksanakan di Sekolah Luar Biasa Budi Nurani, yang lokasinya terletak di jalan Lio Balandongan no. 12 kelurahan Sudajaya hilir, kecamatan Baros, Kota Sukabumi ini menggunakan pendekatan kualitatif dengan metode penelitian deskriptif. Metode yang dianggap tepat dalam penelitian ini adalah metode analisis deskriptif dengan pendekatan metode kreatif melalui pengembangan Bisindo. Tujuannya adalah untuk mendeskripsikan dan menganalisis data dan informasi yang dikumpulkan sehubungan dengan pembelajaran tari kreatif di SMPLB-B Budi Nurani Kota Sukabumi. Penelitian berlangsung dalam latar belakang alamiah, dimana peneliti sendiri merupakan instrumen utamanya dan analisis data dilakukan dengan induktif kualitatif. Penggunaan metoda dan pendekatan ini berangkat dari tujuan pokok penelitian yaitu mendeskripsikan dan menganalisis pembelajaran seni tari dengan mengembangkan isyarat Bisindo di SLB-B Budi Nurani Kota Sukabumi.

Teknik yang digunakan dalam pengumpulan data yang digunakan antara lain teknik pengamatan (observasi), wawancara, 
dan studi dokumentasi. Ketiga teknik ini digunakan dengan harapan dapat saling melengkapi untuk memperoleh data yang diperlukan, sedangkan jenis data yang diperlukan diklarifikasi menjadi data primer dan data sekunder. Populasi dalam penelitian ini seluruh siswa tunarungu kelas 8 SMPLB-B yang berjumlah 8 orang. Adapun penentuan sample dalam penelitian ini menggunakan sampling jenuh, yang mana semua anggota populasi digunakan sebagai sample hal ini dikarenakan " populasi relative kecil, kurang dari 30 orang “ (Sugiyono, 2008:85).

\section{HASIL DAN PEMBAHASAN}

Siswa Tunarungu memiliki hak yang sama seperti anak yang tidak berkebutuhan khusus dalam hal pendidikan, hal ini tercantum pula dalam UU R.I No 20 tahun 2003 pasal 5, yang menyatakan bahwa "setiap warga Negara mempunyai hak yang sama untuk memperoleh pendidikan yang bermutu, dan Warga Negara yang memiliki kelainan fisik, emosional, mental, intelektual, dan/ atau sosial berhak memperoleh pendidikan khusus".

Pendidikan seni budaya diberikan disekolah karena keunikan perannya yang tak mampu diemban oleh mata pelajaran lain. Keunikan tersebut terletak pada kegiatan ekspresi, estetik, dan kreatif yang ditawarkan melalui pendekatan: "belajar dengan seni, belajar melalui seni," dan "belajar tentang seni,".

Seni budaya memiliki sifat mutilingual, multidimensional, dan multikultur. Multilingual bermakna pengembangan mengekspresikan diri dengan berbagai cara dan media seperti bahsa rupa, bunyi, gerak, peran dan berbagai perpaduannya. Multidimensional bermakna pengembangan beragam kompetensi meliputi konsepsi (pengetahuan, pemahaman, analisis, evaluasi), apresiasi dan kreasi dengan cara memadukan secara harmonis unsur estetika, logika, kinestetik, dan etika. Sifat multikultural mengandung makna pendidikan seni menumbuhkembangkan kesadaran dan kemampuan apresiasi terhadap beragam budaya nusantara dan mancanegara. Hal ini merupakan wujud pembentukan sikap menghargai, bertoleransi, demokratis, beradab, serta kemampuan hidup rukun dalam bermasyarakat dan budaya yang majemuk.

Bidang seni seperti rupa, musik, tari dan teater, memiliki kekhasan tersendiri sesuai dengan kaidah keilmuan masing-masing. Dalam pendidikan seni, aktivitas berkesenian harus menampung ke khasan tersebut yang tertuang dalam pemberian pengalaman mengembangkan konsepsi, apresiassi, dan kreasi.Semua ini diperoleh melalui upaya eksplorasi elemen, prinsip, proses, dan teknik berkarya dalam konteks budaya masyarakat yang beragam. Subtansi kajian sesuai dengan standar kompetensi dan kompetensi dasar.

Ruang lingkup mata pelajaran seni budaya khususnya seni tari, mencakup keterampilan gerak berdasarkan olah tubuh dengan dan/ atau tanpa rangsangan bunyi, apresiasi terhadap gerak tari sederhana.Untuk Sekolah Luar Biasa, diantar keempat bidang seni yang ditawarkan, minimal diajarkan satu bidang seni sesuai dengan kemampuan sumberdaya manusia serta fasilitas yang tersedia. Pada sekolah yang mampu menyelenggarakan pembelajaran lebih dari satu bidang seni, peserta didik diberi kesempatan untuk memilih bidang seni yang diikutinya.

Pembelajaran tari pada siswa tunarungu tingkat SMP di SLB, dengan menggunakan model Bisindo merupakan tata cara dalam berkomunikasi dan bersosialisasi bagi siswa tunarungu, dan tari sebagai bahasa non verbal, dimana didalamnya terdapat elemen gerak yang menjadi isyarat pesan yang disampaikan akan menjadi lebih mudah untuk dipahami, sehingga siswa tunarungu semakin bertambah kepercayaan dirinya dalam mengembangkan 
kreativitas pengembangan diri. Meskipun kelemahannya tidak bisa mendengar, namun panca indera penglihatannya sangat tajam, sehingga ketika mempelajari seni tari maupun berkomunikasinya, mereka akan mengeluarkan pikirannya dalam lambang visual atau gerak tubuh.

Tari dan kehidupan manusia saling bersentuhan. Tari merupakan kegiatan kreatif dan konstruktif yang dapat menimbulkan intensitas emosional dan makna. Seni tari memiliki berbagai unsur musik yang berfungsi sebagai pengiring tari juga sebagai penegasan suasana. Melihat dari fungsinya maka musik memiliki posisi yang penting disamping gerak itu sendiri. Tari merupakan seni yang mempersatukan antara gerakan dengan musik pengiring, media tari menggunakan tubuh manusia sehingga melahirkan bentuk gerakan dari anggota badan dan sangat membutuhkan pendengaran yang baik untuk dapat menyatukan musik dan gerak tari. Kesempurnaan fisik terutama pendengaran tentu merupakan suatu hal yang dirasa begitu penting bagi seseorang untuk bisa melakukan tari yang baik dan benar sesuai irama.

Seni tari yang diajarkan di sekolah merupakan suatu media ekspresi bagi siswa, demikian juga dengan siswa yang memiliki keterbatasan pendengaran (tuna rungu ), tentu keterbatasan itu bukan suatu penghalang bagi siswa tunarungu untuk berekpresi, karena mereka juga mampu mengungkapkan ekspresinya dengan baik meski sekalipun keterbatasan fisik akan sedikit memberi hambatan dalam belajar, terutama ketika berkomunikasi pada saat belajar menari.

Dengan mempelajari seni tari, siswa akan mengetahui banyak nilai-nilai yang didapat dalam sebuah tari. Mulai dari sikap etis, rengkuh, dengan sembahan, sebagai rasa hormat pada penonton pada awal penyajian maupun diakhir penyajian tari, mengajarkan tata-titi sopan santun, mengajarkan tata krama bahwa sebagai mahluk sosial pada setiap datang dan pergi harus mempunyai etika mengucapkan selamat datang dan mohon pamit, yang diungkapkan melalui bahasa tubuh, yang luwes disertai rasa keindahan.

Pembelajaran tidak dilakukan sebatas ceramah, karena akan menjadikan pengajaran pasif dan tidak kreatif, karena pembelajaran kreatif harus membuat siswa senang, aktif dan kreatif dalam pembelajaran. Pendidikan Tari Kreatif di sekolah bukan untuk menjadikan siswa menjadi seniman namun lebih mengarah pada pembentukan pribadi siswa yang apresiatif, kreatif, dan dapat diterapkan dalam bertindak yang direfleksikan dalam kehidupan sehari-hari. Siswa dalam Pembelajaran tari kreatif melahirkan sebuah kreatifitas, siswa mengembangkan potensi yang dimilikinya mampu melahirkan sebuah kreativitas.

Strategi agar siswa mampu menghasilkan sebuah gagasan baru yang mengarah dari sebuah kreativitas, yaitu dengan mengembangkan kreativitas siswa dalam pembelajaran serta mengembangkan kompetensi siswa dengan memenuhi standar proses atau produk belajar dengan cara baru, disain baru, model baru atau sesuatu yang lebih baik daripada yang sudah ada sebelumnya. Kreativitas siswa akan muncul jika adanya pemicu, di antaranya dengan menjadikan bahasa verbal sehari-hari mereka menjadi sebuah sumber belajar yang baru, hingga melahirkan penemuan baru, dengan cara belajar yang lebih variatif, eksplorasi gerak bahasa kedalam sebuah gerak tari, ini menjadi sumber informasi baru, dalam mengembangkan stategi penilaian yang baru dan lebih variatif.

Sebuah karya yang lahir dari kreativitas siswa, itu merupakan produk pada level berpikir tertinggi bagi siswa tunarungu, sebab mereka berkreasi menjadi bagian penting penyempurnaan dari keterbatasannya, dari segi ranah kognitif atau psikomornya yang terbatas, namun siswa tunarungu mampu mengevaluasi hasil sebuah kreasitasnya. 
Kreativitas dalam mencipta/berkreasi bagi sisw tunarungu merupakan suatu pengalaman dalam mengungkapkan dan mengaktualisasikan identitas individu seseorang secara terpadu dalam hubungan eratnya dengan diri sendiri, orang lain, dan alam. Kreativitas juga merupakan proses berpikir dan bertindak kreatif dengan menghasilkan sesuatu yang setidaknya baru, bernilai, dan bermakna baik bagi diri sendiri maupun orang lain.

Pengajaran tari kreatif dengan menggunakan isyarat Bisindo di SMPLB-B, tentu akan mempermudah proses belajar menari bagi siswa tunarungu, dengan melihat isyarat jari atau tangan yang dilakukan guru, maka anak tunarungu mudah memahami kode-kode tari yang disampaikan guru dalam penyampaian materi tari sesuai ritmiknya. Pengembangan Bisindo dalam pembelajaran seni tari khususnya, sebagai pengantar materi dan instruksi guru pengajar dalam praktek menari. Dalam seni tari terdapat beberapa simbol kosakata yang melambangkan gerak tertentu yang penggunaan istilah tersebut hanya digunakan dalam bahasa tari. Contoh dari simbol kosakata tersebut adalah obah bahu, kebut sampur, sembah dan beberapa istilah lainnya. Untuk memudahkan penyampaian materi maka dibuat beberapa istilah agar mempermudah penyampaian materi dengan Simbol yang dipergunakan mirip dengan Bisindo, yang intinya mempergunakan jari dan tangan untuk mengganti bahasa verbal atau menyimbolkan pernyataan tertentu.

Pengajaran yang peneliti lakukan di SMPLB-B Budi Nurani Kota Sukabumi, berawal dari mengajukan sebuah pertanyaan yang sangat sederhana kepada siswa, serta membantu siswa mengembangkan kemampuan berpikir, memecahan masalah, dalam keterampilan serta intelektualnya, mengajak mereka untuk dapat menari dengan cara menstimulusnya melalui pengamatan apresiasi langsung serta melakukan diskusi, mengajarkan siswa tunarungu menjadi pembelajar yang mandiri dan kreatif. Materi pelajaran tari kreatif dengan mengembangkan Bisindo di SMPLB-B Budi Nurani Kota Sukabumi, sengaja peneliti penerapan tari tidak dipelajarinya dari buku atau video tari, tetapi dari gerak isyarat-isyarat yang keluar ketika mereka berkomunikasi, sehingga siswa mampu melakukan pengamatan atau melakukan eksperimen/percobaan gerak tarinya mengembangkan dari isyarat komunikasi mereka, dan dijadikan sebuah gerak tari, salah satu contoh ketika jari mereka menandakan hurup $\mathrm{x}$, maka gerak tari mereka menggunakan pola lantai silang, dengan cara ini dapat meningkatkan motivasi siswa dalam melakukan gerak tari dalam pembelajaran seni tari.

Pada proses pembelajaran tari kreatif dengan pengembangan Bisindo, dapat menggali kreatifitas siswa dengan menggali imajinasinya, siswa tunarungu dapat mengekplorasi gerak tubuhnya seperti gerak isyarat komunikasi Bisindo, sehingga siswa tunarungu akan mampu menemukan gerak yang akan disusun menjadi gerak tari. Hasil kreativitas dari imajinasi siswa akan berpengaruh terhadap keberanian siswa, dimana siswa juga akan mampu menampilkan hasil kreasinya dengan rasa percaya diri, juga bekal dalam menambah pengalamannya dalam bidang seni tari.

Keterlibatan siswa dalam proses belajar tari kreatif menjadikan mereka berperan aktif sebagai partisipan dalam proses belajar mengajar. Guru terus berupaya untuk memberi kesempatan kepada siswa untuk aktif mencari, memproses dan mengelola perolehan belajarnya. Keterlibatan siswa dalam proses belajar mengajar secara langsung, siswa secara individual menciptakan peluang yang mendorong siswa untuk melakukan eksperimen, serta berupaya memperoleh informasi, merangkum atau menyimpulkan pesan pembelajaran.

Partisipasi aktif siswa tunarungu dalam tari 
kreatif dengan pengembangan Bisindo sangat berpengaruh pada proses pembelajaran yang terjadi di kelas, siswa tunarungu juga dapat mengembangkan pola berpikir, emosi, serta rasa sosialnya. Keterlibatan siswa dalam belajar, membuat siswa secara aktif terlibat dalam proses pembelajaran tari dan mengambil keputusan gerak kode tari, dengan menggunakan metode belajar dengan melibatkan siswa tidak merasa bosan atau jenuh sehingga pembelajaran seni tari tersampaikan tanpa menghambat perkembangan aktivitas siswa.

Pengajaran tari kreatif bagi siswa tunarungu tidak hanya lancar sampai pembelajaran berakhir di kelas, tapi juga harus mampu sampai penanaman pemahaman atau penguasaan kompetensi siswa. Memberi kesempatan kepada siswa untuk berlatih pengetahuan dan keterampilan yang dipelajari, menjadikan pembelajaran yang interaktif, siswa diajak membuat sebuah gerak, mematuhi ritmik gerak, serta berkomitmen membuat pola lantainya, sehingga pembelajaran terlaksana dengan baik. Di samping itu, dengan mengarahkan siswa terlibar dalam menerapkan pengetahuan dan keterampilan yang dipelajarinya, akan memberi manfaat dalam kehidupan nyata juga sangat membantu menggali pengetahuan dan keterampilan yang dimilikinya. Memberi kesempatan kepada siswa untuk mendalami pengetahuan dan keterampilan yang dipelajarinya, menumbuhkan potensi siswa dengan proses pengajaran yang berpikir kritis dalam segala bentuk ekplorasi pengetahuan dan gerak dari diri siswa.

Interaksi dalam belajar bersama siswa tunarungu, membuat siswa merasa senang ketika belajar dan mereka konsisten dengan hasil belajarnya, mereka merasa lebih bermakna ketika mampu mengembangkan diri nya. Siswa tidak merasa takut ketika bereksperimen, karena hasil eksperimennya benar-benar diterapkan juga dengan rekan sebayanya dikelas, sehingga mereka lebih asyik belajar, betah tinggal di kelas, serta daya serap para siswa terhadap materi pelajaran juga terhitung cepat. Siswa mampu menumbuhkan daya kreativitas, mendorong keterlibatan rekannya, serta mengerjakan keterampilan tarinya, lebih menarik, menyenangkan, dan efektif.

Proses pembelajaran terhadap siswa dengan pengembangan Bisindo, guru lebih memahami potensi siswa yang tersembunyi dan mendorongnya untuk berkembang sesuai dengan kecenderungan bakat mereka, kemudian juga memberikan kesempatan kepada siswa untuk belajar meningkatkan rasa tanggung jawab dalam melaksanakan tugas, menghargai potensi siswa yang lemah dan mendorong siswa untuk terus maju mencapai sukses dalam bidang tari sampai dia mampu berprestasi kedepannya, lebih memahami ragam keindahan dari perbedaan potensi, karakter, serta gaya belajar individu siswa. Dengan metode komunikasi Bisindo, membiasakan peserta didik untuk belajar secara aktif dan membudayakan sikap berani bertanya, tidak minder dan tidak takut salah, karena guru dan murid secara bersamasama mengembangkan fisik dan mental dan bertindak aktif, kreatif, dan menyenangkan dalam proses pembelajaran yang memiliki tujuan sama dalam mencapai pengalaman positif terhadap pengetahuan dan psikologi yang telah diperolehnya.

\section{KESIMPULAN}

Dari hasil penelitian yang telah ditemukan dari hasil lapangan sesuai dengan tujuan penelitian yaitu mendeskripsikan hasil pembelajaran tari kreatif dengan pengembangan Bisindo bagi siswa tunarungu SMPLB-B Budi Nurani Kota Sukabumi, peneliti menyimpulkan bahwa proses pembelajaran tari kreatif melalui pengembangan Bisindo dapat menggali kreativitas siswa, pelaksanaan kegiatan belajar mengajar seni tari dengan metode kreatif membuat siswa senang dalam 
menerima pembelajaran, sehingga siswa dapat menumbuhkan minat dalam bidang tari serta mengekplorasi bakat yang dimilikinya.

Tari kreatif dengan mengembangkan Bisindo, mendorong siswa dalam menuangkan ide atau gagasannya yang dilakukannya secara bebas. Guru sepenuhnya dapat menerima gagasan mereka meskipun itu sederhana. Mengajukan sebuah pertanyaan yang sangat sederhana kepada siswa, mampu membantu siswa mengembangkan kemampuan berpikir, memecahkan masalah, dalam keterampilan serta intelektualnya, mengajak mereka untuk dapat menari dengan cara menstimulusnya melalui pengamatan apresiasi langsung serta melakukan diskusi.

Penerapan tari kreatif pada tunarungu dilakukan dengan pendekatan suasana kasih sayang dan stimulus mental, dimana siswa dirangsang daya kreativitasnya dengan pujian jika mereka berhasil menemukan sebuah gerak dan disesuaikan dengan iringan tarinya. Stimulus yang dilakukan dengan terlebih dulu mengajak mereka menonton pertunjukan langsung juga melihat tayangan video tari. Aktifitas tersebut dilakukan di ruangan itu untuk memfungsikan jiwa siswa agar dapat merasakan, berfantasi, berfikir, berkehendak (karsa) dengan kemampuan motorik mereka dalam merespon serta melatih kepekaan jiwanya.

Pengajaran tari kreatif bagi siswa tunarungu tidak hanya sekedar mentranformasikan ilmu, namun juga harus menciptakan rasa aman dan nyaman bagi siswa, agar mendorong keberanian siswa untuk mencoba berkreasi sesuai kemampuannya, dan guru harus memberi penghargaan atau pujian atas keberhasilan eksplorasinya meskipun sederhana, sehingga pengajaran akan bervariasi dalam suasana yang menyenangkan serta memacu kreativitas siswa, sehingga tari yang merupakan warisan kebudayaan Indonesia yang agung itu dapat dilestarikan disetiap kalangan dan generasi kehidupan manusia.

Tari kreatif melalui pengembangan Bisindo, mampu mengkonstruksi pengetahuan siswa sehingga mereka dapat melepaskan diri dari pola-pola biasa, yang biasa pengajaran hanya dilakukan dengan mengikuti arahan dari guru, kini siswa mampu menuangkan ide nya kedalam sebuah kreatifitasnya yang unik dan berguna.

Proses belajar tari kreatif bisa terjadi dimana saja, tidak terbatas dalam gedung sekolah dengan situasi anak mendengarkan guru sebagai satu-satunya sumber pengetahuan yang benar dan tidak terbantahkan, Tetapi memberi kesempatan dan ruang dialog bagi murid untuk berdiskusi agar terjadinya kesesuaian antara yang disampaikan guru dengan pemahaman siswa.

Pembelajaran tari kreatif dilaksanaknan di SMPLB-B Kota Sukabumi, dapat meningkatkan kreatifitas siswa dalam tari, yang akan melahirkan siswa mampu mencipta sesuai dengan kemampuan dan karakteristiknya. Dalam pelaksanaan pembelajaran seni tari yang menggunakan model Bisindo yang dilakukan secara bereksperimen mampu mengembangkan keterlibatan siswa secara aktif dalam pembelajaran seni tari. Dapat disimpulkan pula adanya pengaruh positif yang signifikan pada materi gerak tari terhadap hasil yang di eksplorasikan, mengembangkan Bisindo dalam pembelajaran tari di SLB-B Budi Nurani Kota Sukabumi dapat meningkatkan keaktifan siswa dan meningkatkan hasil belajar siswa, sehingga siswa tunarungu juga mampu mencipta atau menarikan tari dengan menggunakan level dan pola lantai sesuai dengan musik pengiringnya. 


\section{DAFTAR PUSTAKA}

Ardjo, Durban Irawati. (2008). Kawit Teknik Grak \& Tari Dasar Sunda.Bandung:Pusbitari Press

Direktorat Pembinaan Sekolah Luar Biasa (2006). Standar Kompetensi Dan Kompetensi Dasar,Sekolah Menengah Pertama Luar Biasa Tunarungu (SMPLB-B). Badan Standar Nasional Pendidikan Jakarta

Direktorat Pembinaan SLB. (2009). Pengembangan Kurikulum:Jakarta

Desfina, Dr., M.Hum. (2008) Tari kreatif untuk mengembangkan keterampilan gerak anak. Jurnal Pendidikan Anak Usia Dini . Edukid. Bandung PG PAUD UPI

Sediawati, edi. Dkk. (1986). Pengetahuan elementer tari dan beberapa masalah tari. Direktorat kesenian proyek pengembangan kesenian Jakarta departemen pendidikan dan kebudayaan. Jakarta.

Sutjihati Soemantri. 2006. Psikologi Anak Luar Biasa. Bandung: Refika Aditama.

Sutjihati, T. (2007). Psikologi Anak Luar Biasa. Bandung : Refika Aditama.

Sugiyono.(2008), Metode Penelitian Pendidikan ,Pendekatan Kuantitatif,Kualitatif dan $R \& D$,

Panduan Pengembangaan Kurikulum dan Program Pembelajaran bagi Siswa MDVI/ Deafblinad, direktorat pembinaan pendidikan khususu dan layanan khusus pendidikan dasar direktorat jenderal pendidikan dasar-kemdikbud. Perkins International.2013

http://anaktunarungu.multiply.com/journal/item/1

http://solider.or.id/2015/03/05/sistem-isyarat-bahasaindonesia-vs-bahasa-isyarat-indonesia 